\title{
Fare for liv og helse
}

«Det er i ferd med å utvikle seg til en medisinsk katastrofe une catastrophe sanitaire,» advarte Patrick Pelloux i et åpent brev til Frankrikes president Nicolas Sarkozy 30.12. 2008. Han skrev ikke om situasjonen i Gaza eller i Kongo, men om sykehussenger i Paris-området. Hva hadde skjedd? Frankrike er kjent for å ha et av verdens beste helsevesener og kom ut helt på topp da WHO foretok en rangering i 2001. Alt er selvsagt ikke idyll. Utgiftene øker raskere enn budsjettene, og det er samtidig gjennomført en arbeidstidsreform (35-timersuke). Det må spares og prioriteres. Den franske helseministeren Roselyne Bachelot har varslet en reform for å rasjonalisere driften og bedre samhandlingen og kommunikasjonen internt i sykehusene og mellom de ulike ledd i helsetjenesten. Slikt skaper friksjon.

Patrick Pelloux er leder for foreningen for akuttmedisinske leger i Frankrike og er bekymret. Pelloux og hans fagforening hevder at sykehusene, ikke minst i Paris, ikke lenger er i stand til å garantere pasientenes sikkerhet. Han mener årsaken er at sengekapasiteten er redusert til et uansvarlig lavt nivå fordi det mangler penger på slutten av året. Fjerde juledag døde en 57 år gammel mann med hjerteproblemer etter at han var blitt transportert i ambulanse i seks timer til mer enn 20 ulike sykehus før han endelig fikk slippe inn i mottakelsen. Episoden var den foreløpig siste i en rekke hendelser med dødelig utgang på franske sykehus - dødsfall som mange mener kunne vært unngått. Dette var den umiddelbare bakgrunnen for nyttårsbrevet til presidenten. Men er det grunnlag for å snakke om krise og bruke et uttrykk som «medisinsk katastrofe»?

Hendelser som oppleves som en kritisk trussel mot helse, sikkerhet og livskvalitet, kan med rette betegnes som en truende medisinsk eller humanitær katastrofe. Men hva som defineres som en krise, vil variere med omstendigheter og ståsted. I situasjonen som er beskrevet over, mente f.eks. den franske helseministeren at franske sykehus både hadde tilstrekkelig kapasitet og var trygge, mens redaktøren i en av Frankrikes viktigste aviser, Le Figaro, mente at det vesentlig dreide seg om fagforeningspolitikk (1).

Når dette skrives, ruller grufulle bilder fra sykehus i Gaza over TVskjermene. Våre norske kolleger, Mads Gilbert og Erik Fosse har som de eneste vestlige leger - befunnet seg midt i marerittet og gjort en svær innsats. De har rapportert til mediene og operert skadede om hverandre. Noen har hevdet at informasjonen som kommer ut, er skjev og mangelfull. En viktig årsak til det er i så fall at internasjonal presse og hjelpeorganisasjoner ble nektet innreise og innsyn i krigsområdene. Israelske myndigheter nektet frem til 5.1. 2009 selv et akuttmedisinsk team fra Den internasjonale Røde Kors-komiteen (ICRC) adgang til Gaza. Vi vet og ser likevel mer enn nok. Situasjonen for befolkningen er prekær, uttalte Sven Mollekleiv, president i Røde Kors, og minnet om at statene som grenser til Gaza har forpliktelser i henhold til Genèvekonvensjonene $(2,3)$. De - i dette tilfellet både Israel og Egypt - er forpliktet til å sørge for tilgang til humanitær hjelp i et konfliktområde.

Når det oppstår en krigssituasjon, settes deler av menneskerettighetene til side. Da gjelder egne regler for selve krigshandlingene (Haagkonvensjonene) og for beskyttelse av ofrene i krig (Genève- konvensjonene) (4). I disse skilles det klart mellom stridende (soldater) og ikke-stridende (sivile), mellom militære mål og beskyttede objekter. Beskyttede personer er sivile, krigsfanger, sanitetspersonell og andre med behov for særskilt vern (sivilforsvaret, militærprester og personell i hjelpeaksjoner) (4). Den internasjonale Røde Kors-komiteen er formelt anerkjent i og tillagt oppgaver etter Genèvekonvensjonene. Det er som vokter og håndhever av disse at Røde Kors har sin spesielle plass blant verdens mange humanitære organisasjoner. Derfor var det spesielt ille at det tok så lang tid før de slapp inn i Gaza.

Den humanitære situasjonen for befolkningen i Gaza er prekær - og har vært det lenge. Fordelen er at de i øyeblikket har verdens øyne rettet mot seg. Det gir et ørlite håp. Svært mange mennesker lider og har et enormt behov for hjelp, mat og medisiner uten å få særlig mye oppmerksomhet. Leger Uten Grenser publiserer jevnlig en liste over de ti mest underrapporterte humanitære krisene. I $2008 \mathrm{skrev}$ de (5): «Oppmerksomhet rundt en humanitær krise er en forutsetning for å avhjelpe den. Pressedekningen krisene på Leger Uten Grensers liste får, står overhodet ikke i forhold til de menneskelige lidelsene de forårsaker. Formålet med lista er å rette søkelyset mot enorme humanitære problemer som rammer millioner, men som ikke når opp i konkurransen om internasjonale mediers oppmerksomhet.»

Samtidig dør om lag 1500 kvinner hver eneste dag pga. komplikasjoner i forbindelse med svangerskap og fødsel. 11 millioner barn under fem år dør hvert år av sykdommer som kunne vært forebygd og behandlet (6). Det kan kanskje ikke betegnes som medisinske katastrofer, men de helsemessige konsekvensene og vår manglende evne til å gjøre relativt enkle ting som kunne bedret situasjonen, må kunne betegnes som katastrofale.

Tilgang til nødvendige helsetjenester når man trenger dem, er en viktig betingelse for et godt og verdig liv. Som leger er vi i den privilegerte, men også krevende situasjon at vi er de nærmeste til å definere hva som medisinsk sett er nødvendig, og hva som ikke holder mål eller er uakseptabelt. Vi har ansvar og plikt til å si ifra når vi ser uholdbare forhold for syke og skadede. Det er det Gilbert og Fosse, Leger Uten Grenser, WHO og også den franske fagforeningslederen Patrick Pelloux har gjort. Men vi har - som gruppe også et særlig ansvar for å kalibrere språkbruken slik at hjelpen og innsatsen kommer frem til dem som trenger det mest.

\section{Charlotte Haug}

redaktør

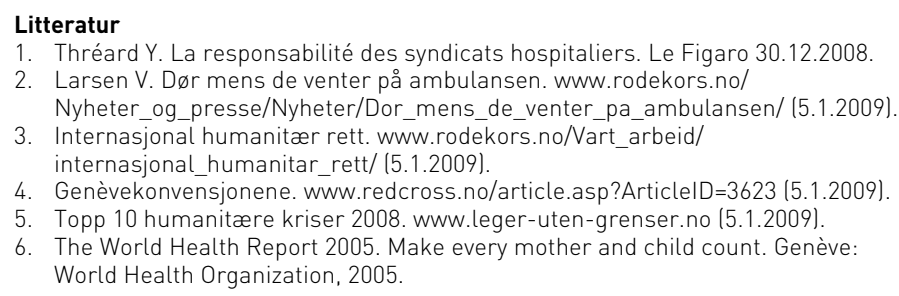

